\title{
CHARACTERISTICS OF HYDROLYSATE PROTEIN FROM MALONG FISH (Congresox talabon) WHICH HYDROLIZED BY USING PAPAIN ENZYME
}

\section{KARAKTERISTIK HIDROLISAT PROTEIN IKAN MALONG (Congresox talabon) YANG DIHIDROLISIS DENGAN MENGGUNAKAN ENZIM PAPAIN}

\author{
Defri Ilham $^{1}$, Dewita ${ }^{1}$, Rahman Karnila ${ }^{1}$ \\ ${ }^{1}$ Kekhususan Teknologi Hasil Perikanan Magister Ilmu Kelautan, Pascasarjana Universitas Riau, Jl. \\ H.R. Subrantas km 12,5 Simpang Baru, Tampan, Kota Pekanbaru, Riau, 28293 \\ Correspondence Author : defri.ilham.pi@gmail.com
}

\begin{tabular}{l}
\hline I N F O A R T I K E L \\
\hline Submited $: 10$ Desember 2018 \\
Revised $: 15$ Januari 2019 \\
Approved: 16 Januari 2019 \\
\hline
\end{tabular}

Kata kunci:

calcium, fish bone flour, quality
A B S T R A C T

This study aimed to utilize the fishbone waste from different types of fish, Pangasius sp., Clarias sp., Paraplotosus sp. as high calcium of bone flour and determine the quality characteristics of fishbone flour which was produced. The method used was a non-factorial Completely Randomized Design (CRD), with different types of fish bones as treatments which consisting of 3 levels: Pangasius sp. bone (Tp), Clarias sp. bone (Tl), and Paraplotosus sp. bone (Ts) with 3 replications and 9 units of experimental units. The parameters tested were organoleptic, proximate analysis, calcium, phosphorus, and whiteness degrees. The results showed that the Pangasius sp. bone flour ( $\mathrm{Tp}$ ) was the best treatment with characteristics of brilliant appearance, the distinctive aroma of fish was still felt, smooth and dry texture, as well as whiteness degrees that the best treatment in walking catfish bone flour with value $81.30 \%$, referred to whiteness degrees of flour, it is below the range of $80-90 \%$. Meanwhile, the best proximate value was obtained in Paraplotosus sp. bone treatment (Ts) with moisture, ash, fat, protein, carbohydrate, calcium and phosphorus content was $5.71 \%, 54.60 \%, 2.57 \%, 25.21 \%$, $10.83 \%, 38.4 \%$, and $33.9 \%$.

\section{PENDAHULUAN}

Indonesia merupakan negara kepulauan dengan potensi kelautan yang besar. Produksi perikanan tangkap Indonesia pada tahun 2014 sebesar 6,4 juta ton yang terdiri dari 6 juta ton produksi perikanan laut dan 447 ribu ton produksi perairan umum. Sektor perikanan laut mengalami kenaikan, yaitu dari 4,8 juta ton pada tahun 2009 menjadi 6 juta ton pada tahun 2014 (Badan Pusat Statistik, 2016).

Provinsi Riau berkontribusi sebesar 107 ribu ton pada tahun 2014 dari total produksi perikanan laut Indonesia, dimana sebesar 1.480 ton berasal dari Kabupaten Bengkalis (Badan Pusat Statistik, 2016). Hal ini menunjukkan bahwa laut Indonesia memiliki potensi besar memenuhi kebutuhan pangan dari ikan. 
Jenis ikan yang berpotensi untuk dimanfaatkan di Kabupaten Bengkalis diantaranya adalah ikan malong (Congresox talabon), juga dikenal dengan nama ikan cunang. Produksi ikan malong berdasarkan pendataan statistik perikanan tahun 2014 sebesar 4,4 ton (Dinas Kelautan dan Perikanan Kabupaten Bengkalis, 2014).

Ikan malong hasil tangkapan nelayan biasanya tidak dalam kondisi utuh, karena gelembung renang (lupe) sudah diambil untuk dijual dalam keadaan kering. Harga gelembung renang kering ikan malong berkisar Rp 5.000.000 per kg, sedangkan ikan malong yang sudah diambil gelembung renangnya dijual berkisar Rp 20.000 - Rp 30.000 per kg. Kartika et al. (2016) menyatakan gelembung renang ikan malong memiliki potensi kolagen yang dicirikan dengan kandungan asam amino glisin, prolin, dan alanine yang tinggi. Tingginya kandungan tiga asam amino tersebut menjadi salah satu penyebab mahalnya gelembung renang ikan malong di pasaran.

Daging ikan malong yang relatif bernilai ekonomi rendah berpotensi untuk dimanfaatkan. Pemanfaatan daging ikan malong sebagai bahan baku pembuatan hidrolisat protein diharapkan dapat meningkatkan nilai tambah (added value) daging ikan malong tersebut. Dewita dan Syahrul (2015) menyatakan bahwa ikan mengandung protein berkualitas tinggi, tersusun dari asam-asam amino yang dibutuhkan tubuh untuk pertumbuhan karena mudah dicerna dan diabsorpsi.

Hidrolisat protein merupakan produk hasil hidrolisis protein yang prinsip pembuatannya adalah pemutusan ikatan peptida pada protein dengan menggunakan enzim (Karnila, 2012). Penggunaan enzim protease pada proses hidrolisis lebih menguntungkan dibandingkan dengan penggunaan asam dan basa. Enzim papain merupakan salah satu enzim protease yang mengkatalisa reaksi pemecahan rantai polipeptida pada protein dengan cara menghidrolisa ikatan peptida menjadi senyawa-senyawa yang lebih sederhana, seperti peptida dan asam amino. Proses hidrolisis dengan menggunakan enzim papain dapat berjalan dengan baik pada kondisi suhu $55^{\circ} \mathrm{C}$ dan $\mathrm{pH} 8,0$ selama 4 jam (Nurhayati et al., 2014).

Penelitian hidrolisat protein diantaranya, Karnila (2012) daya hipoglikemik dari hidrolisat, konsentrat dan isolat protein teripang pasir menggunakan tikus, secara in vitro hidrolisat protein teripang memiliki daya hambat tertinggi terhadap aktivitas enzim $\alpha$-glukosidase dibandingkan dengan isolat protein teripang dan konsentrat protein teripang. Nurhayati et al. (2014) menyatakan bahwa hidrolisat protein jeroan ikan kakap putih memiliki karakteristik mutu dan kandungan asam amino yang tepat untuk diaplikasikan sebagai sumber protein.

Berdasarkan uraian di atas, maka perlu dilakukan kajian tentang karakteristik hidrolisat protein ikan malong. Bahan baku hidrolisat berupa ikan malong yang banyak tersedia untuk dimanfaatkan secara optimal, juga tersedianya bahan penghidrolisa yaitu enzim papain yang dapat digunakan dengan aman.

\section{METODE PENELITIAN}

\section{Bahan dan Alat}

Bahan utama penelitian adalah ikan malong (C. talabon) yang diperoleh dari nelayan Bengkalis dengan bobot 7,58 kg (tanpa gelembung renang) per ekor dengan panjang 1,56 m, enzim papain dengan aktivitas enzim $105.000 \mathrm{U} / \mathrm{g}$ (Xian Lyphar Biotech), dan aquades. Bahan-bahan kimia untuk analisis proksimat $\left(\mathrm{K}_{2} \mathrm{SO}_{4}, \mathrm{CuSO}_{4}, \mathrm{H}_{2} \mathrm{SO}_{4}\right.$, bromocresol green, methyl red, $\mathrm{NaOH} 40 \%(\mathrm{~b} / \mathrm{v})$, $\mathrm{H}_{3} \mathrm{BO}_{3} 4 \%(\mathrm{v} / \mathrm{v})$, dan $\mathrm{HCl}$ ); analisis asam amino total (Ortoftalaldehida (OPA), buffer borat $1 \mathrm{M}, \mathrm{HCl}$ $6 \mathrm{~N}$, gas $\mathrm{N}_{2}$, Na-Asetat 0,025 M, Na-EDTA, metanol 95\% (v/v), THF, merkaptoetanol, Brij-30 larutan standar asam amino $0,5 \mu \mathrm{mol} / \mathrm{ml}$ ); analisis derajat hidrolisis (TCA $20 \%(\mathrm{~b} / \mathrm{v}$ ); Bahan habis pakai antara lain kapas, tissue, aluminium foil, dan aquades.

Alat-alat yang digunakan dalam penelitian ini antara lain timbangan analitik (Boeco), refrigerator (LG), homogenizer (Nissei AM-3), waterbath shaker (Wiggen Hauser), evaporator (Buchi), sentrifuge (Sorvall T-21), oven (Yamato), pH meter (Orion), inkubator (Termolina), mikropipet (Pipetman), spektrofotometer (Yamato), High Performance Liquid Chromatography (Shimadzu), dan freeze drayer.

\section{Persiapan (preparasi daging ikan malong) dan analisis komposisi kimia (proksimat)}


Tahap awal, untuk mengetahui kondisi dari daging ikan malong yang digunakan, maka ikan malong terlebih dahulu dipisahkan antara bagian daging dengan bagian tubuh lainnya (kepala, kulit, tulang, insang, jeroan). Selanjutnya daging ikan malong dicuci dan dilakukan pemotongan serta pencincangan untuk pengecilan ukuran, kemudian dilakukan analisis proksimat (kadar air, kadar abu, kadar protein, kadar lemak, dan karbohidrat).

\section{Pembuatan hidrolisat protein ikan malong}

Pembuatan hidrolisat protein ikan dilakukan melalui reaksi hidrolisis enzimatis menggunakan enzim papain. Percobaan pembuatan hidrolisat dilakukan dengan menggunakan metode Karnila (2012) dan Nurhayati et al. (2014) yang dimodifikasi. Pada tahap awal potongan kecil daging ikan malong dilakukan proses pengeringan $\left(40^{\circ} \mathrm{C}\right)$, kemudian dilakukan penggilingan (penepungan) mencapai ukuran 80 mesh. Selanjutnya tepung ikan malong dicampur dengan aquades (perbandingan 1 : 10; 1 bagian tepung ikan malong dicampur dengan 10 bagian aquades) serta dilakukan homogenisasi selama 2 menit. Kemudian dilakukan perebusan pada suhu $85{ }^{\circ} \mathrm{C}$ selama 15 menit dan pendinginan. Setelah itu, homogenat tersebut ditambahkan enzim papain dengan konsentrasi $\mathbf{M}_{1}=$ $0,125 \%(\mathrm{~b} / \mathrm{v}), \mathrm{M}_{2}=0,150 \%(\mathrm{~b} / \mathrm{v})$, dan $\mathrm{M}_{3}=0,175 \%(\mathrm{~b} / \mathrm{v})$. Pada hidrolisat ikan malong difokuskan untuk mengamati pengaruh perbedaan konsentrasi enzim, sedangkan faktor lain dikontrol untuk tetap stabil seperti penggunaan suhu hidrolisis optimum $55^{\circ} \mathrm{C}$ dan $\mathrm{pH} 8,0$ selama 4 jam. Penggunaan suhu, $\mathrm{pH}$, dan waktu hidrolisis berdasarkan penelitian yang dilakukan oleh Nurhayati et al. (2014) yang meneliti tentang hidrolisat protein jeroan ikan kakap putih. Selanjutnya dilakukan perebusan pada suhu $85^{\circ} \mathrm{C}$ selama 15 menit untuk menginaktifkan enzim. Setelah proses hidrolisis selesai, dilanjutkan dengan pemisahan supernatan (fasa cair) dari presipitan (residu) menggunakan sentrifugasi (6 $500 \mathrm{x} \mathrm{g}$ selama 15 menit). Supernatan yang diperoleh, dievaporasi dengan menggunakan rotary vacum evaporator sampai semua pelarut menguap. Hasil evaporasi yang diperoleh pada tahap ini merupakan hidrolisat ikan malong dan selanjutnya dilakukan freeze drying. Hidrolisat yang diperoleh dikemas dalam botol sampel dan aluminium foil serta disimpan dalam cool room pada suhu $4^{\circ} \mathrm{C}$ sampai siap digunakan pada tahap pengamatan.

\section{Penentuan kondisi optimum (konsentrasi enzim papain) dalam proses hidrolisis protein}

Pengukuran derajat hidrolisis menggunakan metode Hasnaliza et al. (2010). Derajat hidrolisis dihitung berdasarkan persentase rasio trichloroacetic acid (TCA). Sebanyak $20 \mathrm{~mL}$ hidrolisat protein ditambahkan TCA 20\% (b/v) sebanyak $20 \mathrm{~mL}$. Campuran tersebut kemudian didiamkan selama 30 menit agar terjadi pengendapan, lalu disentrifugasi (kecepatan $7800 \mathrm{x}$ g, selama 15 menit). Supernatannya lalu dianalisis kadar nitrogennya menggunakan metode Kjeldahl (AOAC, 2005). Derajat hidrolisis dapat dihitung dengan rumus :

Derajat hidrolisis $=\frac{\text { Nitrogen terlatut } \mathrm{TCA} 10 \%}{\text { Nitrogen total sampel }} \times 100 \%$

\section{Karakteristik hidrolisat protein ikan malong}

Karakteristik dilakukan terhadap hidrolisat protein ikan malong yang dihasilkan dari reaksi enzimatis pada kondisi optimum dengan cara dianalis. Analisis yang dilakukan yaitu (1) proksimat (kadar air, kadar abu, kadar protein, kadar lemak, dan karbohidrat); (2) jenis dan kadar asam amino; dan (3) rendemen.

\section{Analisis Data}

Rancangan percobaan yang digunakan adalah Rancangan Acak Lengkap (RAL) dengan perbedaan konsentrasi enzim sebagai perlakuan dan setiap perlakuan dilakukan tiga kali ulangan. Perlakuan yang digunakan dalam penelitian adalah $\mathrm{M}_{1}=0,125 \%(\mathrm{~b} / \mathrm{v}), \mathrm{M}_{2}=0,150 \%(\mathrm{~b} / \mathrm{v}), \mathrm{M}_{3}=$ $0,175 \%(\mathrm{~b} / \mathrm{v})$. Data yang diperoleh dianalisis dengan sidik ragam (ANOVA) dan dilanjutkan dengan uji Duncan untuk melihat perbedaan masing-masing perlakuan.

\section{HASIL DAN PEMBAHASAN}

\section{Proksimat daging dan tepung ikan malong}


Bagian ikan malong yang digunakan sebagai bahan baku pembuatan hidrolisat pada penelitian ini adalah bagian daging, sedangkan bagian lain seperti kepala, kulit, tulang, insang, dan jeroan tidak digunakan. Daging ikan malong selanjutnya diproses menjadi tepung. Hasil analisis proksimat daging dan tepung ikan disajikan pada Tabel 1.

Tabel 1 menunjukkan kadar protein daging ikan malong sebesar 79,26\% cukup tinggi dan berpotensi untuk dimanfaatkan sebagai bahan pangan. Penggunaan suhu yang lebih rendah mampu mengurangi kerusakan pada protein. Kadar protein yang dihasilkan setelah proses pengeringan dan menjadi tepung sebesar $77,16 \%$. Sampel dalam bentuk tepung diharapkan dapat lebih homogen dalam proses pembuatan hidrolisat protein.

Vaclavik dan Christian (2008) menyatakan bahwa protein terdiri atas rantai asam amino yang dihubungkan dengan ikatan peptida sehingga membentuk beragam struktur yang kompleks. Asam amino sangat berguna dalam sintesis protein pada pembentukan otot. Siklus protein dapat terjadi dalam sel, jaringan atau dalam badan dan melibatkan saluran pencernaan (Karnila, 2012). Kondisi ini diduga menyebabkan kandungan protein terbesar pada ikan malong terdapat pada bagian daging.

\section{Derajat hidrolisis}

Penentuan kondisi optimum (konsentrasi enzim papain) dalam proses hidrolisis protein ikan malong dengan menghitung derajat hidrolisis. Nilai rata-rata derajat hidrolisis hidrolisat protein ikan malong dengan konsentrasi enzim papain yang berbeda disajikan pada Gambar 1 .

Gambar 1 menunjukkan perbedaan nilai derajat hidrolisis pada setiap konsentrasi enzim papain yang digunakan. Hasil analisis ragam menunjukan bahwa konsentrasi enzim papain berpengaruh sangat nyata terhadap derajat hidrolisis yang dihasikan $(\mathrm{p}<0,01)$. Hasil uji lanjut Duncan menunjukan bahwa $M_{2}$ berbeda sangat nyata dengan $M_{1}$ dan $M_{3}$, serta $M_{1}$ berbeda sangat nyata dengan $\mathrm{M}_{3}$.

Derajat hidrolisis maksimum diperoleh dari perlakuan $\mathrm{M}_{2}$ sebesar $99,06 \%$ dan merupakan kondisi optimum dalam proses hidrolisis protein ikan malong. Penambahan konsentrasi enzim pada $\mathrm{M}_{1}$ dan $\mathrm{M}_{2}$ menyebabkan meningkatnya derajat hidrolisis yang dihasilkan. Namun pada perlakuan $\mathrm{M}_{3}$ derajat hidrolisis yang dihasilkan menurun. Semakin besar konsentrasi enzim papain yang ditambahkan, nilai derajat hidrolisis hidrolisat protein juga semakin besar, namun pada konsentrasi tertentu nilai derajat hidrolisis cenderung tetap atau tidak mengalami perubahan ya+ng signifikan (Nurhayati et al., 2013). Lehninger (1993) menyatakan bahwa kondisi tersebut menyebabkan enzim menjadi jenuh oleh substratnya dan tidak dapat berfungsi lebih cepat.

\section{Karakteristik hidrolisat protein ikan malong}

Hidrolisat protein ikan malong yang dihasilkan memiliki beberapa karakteristik amino total, dan rendemen. Hasil analisis proksimat hidrolisat protein ikan malong disajikan pada Tabel 2.

Kadar air yang terkandung pada hidrolisat protein ikan malong sebesar 10,66\% lebih rendah dibandingkan dengkadar air hidrolisat protein ikan gabus sebesar 10,75\% (Prastari et al., 2017) dan kadar air hidrolisat protein ikan bandeng sebesar 96,41\% (Wijayanti et al., 2016). Kadar air hidrolisat protein ikan malong yang tidak jauh berbeda dengan hidrolisat protein ikan gabus disebabkan penggunaan metode pengeringan yang sama, yaitu freeze drying, sedangkan hidrolisat protein ikan bandeng berbentuk cair.

Hidrolisat protein ikan malong memiliki kadar abu sebesar 7,22\% lebih rendah dibandingkan dengan kadar abu hidrolisat protein ikan gabus sebesar 10,75\% (Prastari et al., 2017) dan kadar abu hidrolisat protein ikan bandeng sebesar 10,61\% (Wijayanti et al., 2016). Penambahan senyawa alkali, seperti $\mathrm{NaOH}$ dan atau senyawa asam, seperti $\mathrm{HCl}$, dalam proses hidrolisis protein bertujuan untuk mencapai nilai $\mathrm{pH}$ optimum enzim dan menjaga agar $\mathrm{pH}$ tetap konstan selama proses hidrolisis sehingga pemutusan ikatan peptida oleh enzim dapat tetap berlangsung (Wijayanti et al., 2016). Gesualdo dan Li-Chan (1999) menyatakan bahwa pencampuran senyawa asam dan alkali dalam larutan hidrolisat protein akan menyebabkan terbentuknya senyawa garam, sehingga dapat meningkatan kadar abu pada hidrolisat protein. Hidrolisat protein ikan malong memiliki kadar protein yang tinggi sebesar $91,04 \%$. Hal ini menunjukkan penggunaan enzim papain berjalan optimal dalam proses hidrolisis protein. Enzim papain tergolong dalam kelompok enzim endopeptidase yang berperan dalam memutuskan ikatan peptida secara spesifik pada bagian tengah rantai protein (Grzonka et al., 2007). 


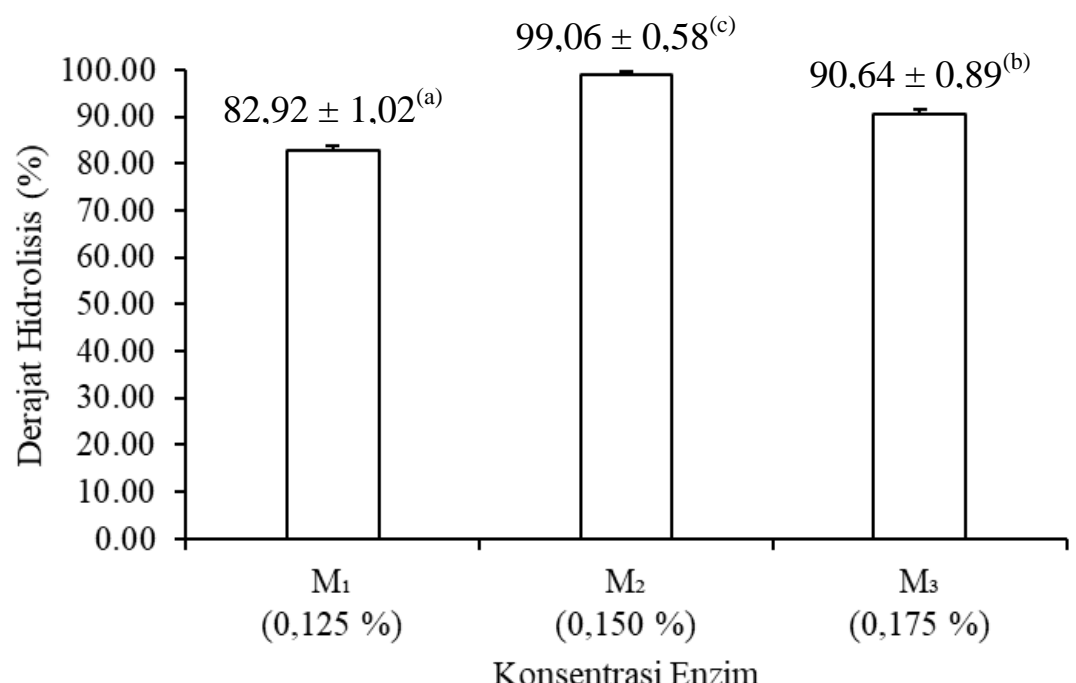

Gambar 1. Nilai rata-rata derajat hidrolisis hidrolisat protein ikan malong dengan konsentrasi enzim papain yang berbeda. Keterangan : angka yang diikuti oleh huruf yang berbeda menunjukkan perbedaan sangat nyata $(\mathrm{p}<0,01)$

Tabel 1. Proksimat daging dan tepung ikan malong

\begin{tabular}{lrr}
\hline Komposisi & \multicolumn{1}{l}{ Daging } & \multicolumn{1}{l}{ Tepung } \\
\hline Air (bb) & $74,78 \pm 0,03$ & $10,12 \pm 0,07$ \\
Abu (bk) & $13,48 \pm 0,76$ & $11,46 \pm 0,15$ \\
Protein (bk) & $79,26 \pm 0,43$ & $77,16 \pm 0,07$ \\
Lemak (bk) & $0,49 \pm 0,07$ & $1,10 \pm 0,38$ \\
Karbohidrat $*$ & $6,77 \pm 0,59$ & $10,28 \pm 0,49$ \\
(bk) & & \\
\hline
\end{tabular}

* by difference

Tabel 2. Proksimat hidrolisat protein ikan malongAnalisis proksimat hidrolisat protein ikan malong

\begin{tabular}{lc}
\hline Komposisi & Persentase $(\%)$ \\
\hline Air (bb) & $10,66 \pm 0,06$ \\
Abu (bk) & $7,22 \pm 0,18$ \\
Protein (bk) & $91,04 \pm 0,09$ \\
Lemak (bk) & $0,33 \pm 0,34$ \\
Karbohidrat* (bk) & $1,41 \pm 0,57$ \\
\hline
\end{tabular}

* by difference

Tabel 3. Komposisi asam amino total hidrolisat rotein ikan malong

\begin{tabular}{llll}
\hline Asam Amino Esensial & Persentase $(\%)$ & Asam Amino Non Esensial & Persentase (\%) \\
\hline Arginin & 1,21 & Alanin & 1,01 \\
Fenilalanin & 1,30 & Asam Aspartat & 3,48 \\
Histidin & 1,59 & Asam Glutamat & 9,44 \\
Isoleusin & 2,02 & Glisin & 2,88 \\
Leusin & 4,93 & Prolin & 3,12 \\
Lisin & 2,88 & Serin & 1,33 \\
Metionin & 1,75 & Sistein & 0,96 \\
Treonin & 1,98 & Tirosin & 1,00 \\
Valin & 2,84 & & \\
\hline
\end{tabular}


Kadar protein meningkat seiring bertambahnya konsentrasi enzim yang ditambahkan. Kenaikan nilai protein menunjukkan meningkatnya jumlah total nitrogen pada hidrolisat protein ikan karena metode analisis yang digunakan adalah metode Kjeldahl yang menggunakan jumlah nitrogen sebagai konversi pada perhitungan kadar protein. Hal tersebut menunjukkan bahwa dengan bertambahnya konsentrasi enzim maka kecepatan reaksi hidrolisis pun semakin meningkat, namun demikian pada batas tertentu penambahan enzim yang berlebih akan berakibat pada jumlah hidrolisat yang konstan karena penambahan enzim sudah tidak aktif lagi (Wijayanti et al., 2016).

Hidrolisat protein ikan malong memiliki kadar protein sebesar 91,04\% lebih tinggi dibandingkan kadar protein ikan gabus sebesar 90,43\% (Prastari et al., 2017) dan kadar protein hidrolisat protein ikan bandeng sebesar $85,00 \%$ (Wijayanti et al., 2016), hal ini dikarenakan adanya perbedaan penggunaan enzim. Hidrolisis protein ikan bandeng dan hidrolisat protein ikan gabus menggunakan enzim bromelin. Prastari et al. (2017) menyatakan bahwa enzim bromelin yang digunakan pada pembuatan hidrolisat protein gabus menyebabkan terjadi degradasi protein dari bagian rantai-rantai peptida menjadi asam amino.

Kadar lemak hidrolisat protein ikan malong sebesar 0,33\%. Sebagian lemak yang terkandung dalam hidrolisat protein diduga ikut terpisah bersama protein yang tidak terlarut, yaitu ketika sentrifugasi. Hidrolisat protein yang mempunyai kadar lemak rendah umumnya lebih stabil terhadap reaksi oksidasi lemak dibandingkan hidrolisat protein ikan yang mempunyai kadar lemak tinggi (Nilsang et al., 2005). Shahidi et al. (1995) menjelaskan bahwa pada saat reaksi hidrolisis berlangsung, membran sel akan menyatu dan membentuk gelembung yang tidak terlarut, hal tersebut menyebabkan terlepasnya lemak pada struktur membran. Perubahan struktur jaringan ikan yang sangat cepat menyebabkan kadar lemak menurun. Dewita et al. (2017) menyatakan bahwa semakin tinggi daya ekstraksi pelarut terhadap air dan lemak, maka protein akan semakin terkonsentrasi dan lemak akan semakin rendah. Kadar lemak hidrolisat protein ikan malong lebih rendah dibandingkan kadar lemak hidrolisat protein ikan gabus sebesar 1,48\% (Prastari et al., 2017) dan kadar lemak hidrolisat protein ikan bandeng sebesar 0,48\% (Wijayanti et al., 2016).

\section{Jenis dan kadar asam amino total}

Hidrolisat protein ikan malong mengandung 9 jenis asam amino esensial dan 8 asam amino non esensial (Tabel 3). Kandungan asam amino esensial tertinggi pada hidrolisat protein ikan malong adalah leusin $(4,93 \%)$, sedangkan asam amino non esensial tertinggi adalah asam glutamat $(9,44 \%)$. Prastari et al. (2017) menyatakan bahwa protein bermutu tinggi adalah protein yang mengandung semua jenis asam amino dalam proporsi yang sesuai untuk pertumbuhan.

Pembuatan hidrolisat protein ikan malong dengan menggunakan enzim papain menghasilkan asam amino yang cukup tinggi yang disebabkan terjadinya degradasi protein dari bagian-bagian rantai peptida menjadi asam amino. Enzim papain tergolong dalam kelompok enzim endopeptidase yang berperan dalam memutuskan ikatan peptida secara spesifik pada bagian tengah rantai protein (Grzonka et al., 2007).

\section{Rendemen}

Rendemen hidrolisat protein ikan malong sebesar 50,07\%. Konsentrasi enzim, suhu, pH, dan waktu hidrolisis mempengaruhi jumlah rendemen yang dihasilkan. Substrat yang terhidrolisis secara maksimum dapat meningkatkan jumlah rendemen. Karnila (2012) menyatakan bahwa penggunaan enzim pada proses hidrolisis dapat menghasilkan rendemen yang cukup tinggi. Waktu hidrolisis yang digunakan juga sangat mempengaruhi jumlah rendemen yang dihasilkan.

Proses hidrolisis dengan menggunakan enzim, substrat yang digunakan akan diubah menjadi produk hidrolisat. Rendemen produk hidrolisat adalah persentase banyaknya produk hidrolisat yang dihasilkan terhadap berat bahan baku sebelum dihidrolisis (Wijayanti et al., 2016). Terlarutnya komponen gizi seperti lemak, protein, dan mineral selama proses hidrolisis mempengaruhi besarnya rendemen produk hidrolisat yang dihasilkan (Shahidi et al., 1995). Penggunaan air juga mampu memperluas bidang kontak antara enzim dan substrat, sehingga pada rentang waktu tertentu dapat dihasilkan produk hidrolisat yang lebih besar (Wijayanti et al., 2016). Rendemen hidrolisat protein ikan malong yang dihasilkan lebih tinggi dibandingkan dengan rendemen hidrolisat protein ikan gabus, yaitu sebesar 50,01\% (Prastari et al., 2017). 


\section{KESIMPULAN}

Karakteristik hidrolisat protein yang dihasilkan dengan menggunakan enzim papain berwarna putih kekuningan dengan kadar protein sebesar 91,04\% dan rendemen sebesar 50,07\%. Hidrolisat protein ikan malong mengandung 9 jenis asam amino esensial dan 8 asam amino non esensial. Kandungan asam amino esensial tertinggi pada hidrolisat protein ikan malong adalah leusin sebesar 4,93\%, sedangkan asam amino non esensial tertinggi adalah asam glutamat sebesar $\quad 9,44 \%$. Hidrolisat protein yang dihasilkan diperoleh dari kondisi optimum hidrolisis protein ikan malong, yaitu menggunakan enzim papain dengan konsentrasi $0,150 \%(\mathrm{~b} / \mathrm{v})$; suhu $55^{\circ} \mathrm{C} ; \mathrm{pH} 8,0$; dan waktu hidrolisis selama 4 jam.

\section{REKOMENDASI}

Perlu dilakukan penelitin lebih lanjut mengenai hidrolisat protein ikan malong yang terdiri dari beberapa jenis asam amino esensial dan asam amino non esensial sehingga dapat menghasilkan hidrolisat protein dengan menggunakan enzim papain konsentrasi.

\section{DAFTAR ACUAN}

Alberts B, Johnsons A, Lewis J, Raff M, Roberts K, Walter P. 2002. Molecular Biology of The Cell. New York (USA): Garland Science.

Badan Pusat Statistik. 2016. Produksi Perikanan Tangkap menurut Provinsi dan Subsektor (ton), 20002014. Jakarta : Badan Pusat Statistik.

Baehaki A, Lestari SD, Romadhoni AR. 2015. Hidrolisis Protein Ikan Patin Menggunakan Enzim Papain dan Aktivitas Antioksidan Hidrolisatnya. J. Pengolahan Hasil Perikanan Idonesia. 2015, Vol. 18 No. 3.

Belkaaloul K, Checroun A, Ait- Abdesalam A, Saidi D, Kherouoa O. 2010. Growth, acidification \& proteolysis performance of two co-cultures (Lactobacillus plantarum- Bifidobacterium longum and Streptococcus thermophilus bifido-bacterium longum). African J. of Biotechnology. 9(10): 1463-1469.

Dewita and Syahrul. 2015. Quality Assessment of Fish Protein Concentrate from catfish During Storage at Room Temperature. IOSR-JESTFT. Vol. 9, Issue 9 Ver. I (Sep. 2015), pp 20-23.

Dewita, Syahrul, Desmelati. 2018. Functional Characteristics of Cookies Containing Snakehead (Ophiocephalus striatus) Fish Protein Concentrate Fortified with Chlorella sp. International J. of Oceans and Oceanography. Vol. 12, Number 1 (2018), pp 43-52.

Dewita, Syahrul, Suparmi, Lukman S. 2017. Utilization of Fish Protein Concentrate from Patin Fish (Pangasius hypopthalmus) on street foods for Under Five Years Children at Kampar District, Riau Province. International J. of Oceans and Oceanography. Vol. 11, Number 1 (2017), pp $75-88$.

[DKP] Dinas Kelautan dan Perikanan Kabupaten Bengkalis. 2014. Pendataan Statistik Perikanan Tahun 2014. Bengkalis.

Gauthier SF, Vachon C, Jones JD, Savoie L. 1982. Assessment of protein digestability in vitro enzymatic hydrolysis with simultaneous dialysis. J. Nutr. 112: 1718-1725.

Gesualdo AML, Li-Chan ECY. 1999. Functional properties of fish protein hydrolysate from herring (Clupea harengus). J. of Food Science. 64 (6): 1000-1004.

Grzonka Z, Kasprzykowski F, Wiczk. 2007. Cysteine Proteases. Di dalam: Polaina J, MacCabe AP, editor. Industrial Enzymes: Structure, Function and Application. Netherlands : Springer. 
Karnila R. 2012. Daya Hipoglikemik Hidrolisat, Konsentrat, dan Isolat Protein Teripang Pasir (Holothuria scabra j.) pada Tikus Percobaan. [Disertasi]. Bogor : Sekolah Pascasarjana, Institut Pertanian Bogor.

Lehninger AL. 1993. Dasar Biokimia I. Maggy Thenawidjaja, penerjemah. Terjemahan dari: Principles of Biochemistry. Jakarta: Penerbit Erlangga.

Mine Y, Shahidi F. 2006. Nutraceutical proteins and peptides in health and disease. Boca Raton: CRC Press.

Nilsang S, Lertsiri S, Suphantharika M, Assavanig A. 2005. Optimization of enzymatic hydrolysis of fish soluble concentrate by commercial protease. J. of Food Engineering. 70(1): 571-578.

Nurhayati T, Nurjanah, Sanapi CH. 2013. Karakteristik Hidrolisat Protein Ikan Lele Dumbo (Clarias gariepinus). J. Pengolahan Hasil Perikanan Indonesia. Vol. 16, No. 3 Tahun 2013.

Nurhayati T, Salamah E, Cholifah, Nugraha R. 2014. Optimasi Proses Pembuatan Hidrolisat Jeroan Ikan Kakap Putih. J. Pengolahan Hasil Perikanan Indonesia. Vol. 17, No. 1 Tahun 2014.

Prastari C, Yasni S, Nurilmala M. 2017. Karakteristik Protein Ikan Gabus yang Berpotensi Sebagai Antihiperglikemik. J. Pengolahan Hasil Perikanan Indonesia. Vol. 20, No. 2 Tahun 2017.

Salamah E, Nurhayati T, Widadi IR. 2012. Pembuatan dan Karakterisasi Hidrolisat Protein dari Ikan Lele Dumbo (Clarias gariepinus) Menggunakan Enzim Papain. J. Pengolahan Hasil Perikanan Indonesia. Vol. 15 No. 1.

Shahidi F, Han XQ, Synowiecki J. 1995. Production and characteristic of protein hydrolysates from Capelin (Mallotus villosus). J. of Food Chemistry. 53: 285-293.

Vaclavik VA, Christian EW. 2008. Essential of Food Science. Ed ke-3. New York : Springer.

Wijayanti I, Romadhon, Rianingsih L. 2016. Karkateristik Hidrolisat Protein Ikan Bandeng (Chanos chanos Forsk) dengan Konsentrasi Enzim Bromelin yang Berbeda. J. Saintek Perikanan. Vol. 11, No. 2 Tahun 2016. 